\title{
COVID-19, women and digitised food networks in Jakarta: Inequality and resilience
}

Edition 3, 2020

Dr Inaya Rakhmani, Dr Ariane Utomo, Dr Catherine Phillips, Dr Diahhadi Setyonaluri DOI: 10.37839/MAR2652-550X3.13

COVID-19 has disrupted market economies all around the world. As governments take unprecedented action to contain its spread, the pandemic is increasing global food insecurity due to disruptions of food systems and weakening economies.

In Indonesia, income decline associated with government-imposed restrictions on movement and travel have been accompanied by decreased purchasing power for households and food availability in cities. Though the government has instituted some social security measures, over half of respondents to a recent survey by Statistics Indonesia reported increases in food-related expenses due to reductions in food availability and shifts in dietary habits. In Greater Jakarta-one of Asia's mega urban regions with over 30 million people-the critical importance of food provision during a pandemic is complicated by problems stemming from severe flooding earlier this year.

Jakarta is joining the ranks of other global cities as emerging hot-spots of COVID-19. Within the city of Jakarta-excluding its adjoining municipalities-as of August 10 2020, the total reported number of confirmed cases was 26,193 and 940 deaths. Given the relatively low rate of testing, official figures likely underestimate actual cases and deaths. 
The economic impact of the pandemic has been significant for Jakarta households. In mid-April 2020, Indonesia's Ministry of Manpower recorded over 449,500 workers being forced to take leave without pay in Jakarta and, according to J-PAL, by early July 2020 over $50 \%$ of both men and women had lost their jobs.

The pandemic has highlighted the importance of informal food networks in Jakarta, and the essential role that women play in creating, extending, amplifying, and sustaining these networks. Examining the ways in which urban women utilise informal food networks highlights the increasingly blurred boundaries between formalised paid work and informal care work needed to attain food security for their households and communities during the pandemic, and beyond.

\section{Women and urban informal food networks}

Global assessments indicate that urban consumers tend to be more vulnerable to crisis-related food insecurity due to their reliance on bought rather than self-grown food. Research has underlined the importance of informal food networks in achieving urban food security during and post-crisis. Informal food networks encompass a complex range of activities from provisioning through urban agriculture to marketing at street stalls, to neighbourhood composting to deal with household waste. Women are key actors in informal food networks-as consumers, producers, and distributors they develop and sustain these networks across urban communities.

During COVID-19, restrictions on the movement of goods and people have increased reliance on informal food networks and shorter, localised food chains. These networks have become essential for household food security, as they involve a circle of trust that allows the supplying and purchasing of reliable sources of nutrition. They have also provided income-generating opportunities for women and their families. Women's social networks and social media practices have played a particularly important part in enabling informal safety nets centred on the buying, selling, distribution, and donation of food during the pandemic. 


\section{Mobilising Digital Networks}

Given the challenges of food security, income, and health presented by the COVID-19 pandemic, women have proven to be agile in meeting the nutritional needs of their households and in finding supplementary sources of income. During the COVID-19 restrictions on movement, women modifying existing informal food networks through internet-mediated communication has become common across Greater Jakarta's urban neighbourhoods. For example, many mobile vegetable vendors no longer only sell and distribute food because women householders have arranged for orders to be taken via WhatsApp so the vendors now also deliver other essential household and educational items.

Our preliminary observation and recent media reports suggest that the compound crisis of the pandemic has amplified the reach, and elevated the importance, of informal food networks and their digitisation. For instance, on March 2020, a tweet posted by an ordinary Twitter user went viral with more than 8,200 retweets and 14,600 likes. The tweet informed people that vegetable vendors had created a WhatsApp (WA) group comprising of mothers in the neighbourhood (Rukun Warga), which could be used to have orders listed, purchased, and delivered to home terraces.

The role of digital connection in facilitating successful informal food networks during COVID-19 in Jakarta is not surprising. There are approximately 175.4 million internet users in Indonesia, almost half of whom are women, making 338.2 million mobile connections per month. Among the most-used social media platforms are WA messenger (84\%), Instagram (79 \%), and Twitter (56\%). Even before COVID-19, using social media to source goods and generate income was increasingly common for women in urban Indonesia.

During the pandemic, there are indications that informal food networks have acted as an economic safety net, as women navigate the adverse impacts of job and income loss during and post-lockdowns. For example, following the government's instruction 
to remain \#dirumah aja (stay at home), Hizboel (a mother of three and food entrepreneur) who initially sold fruit salad and cooked meals, began selling frozen food for those residing in East Jakarta. She takes orders through online food markets (GrabFood and GoFood) that provide home-delivery services. During the pandemic, her orders have spiked resulting in a gross income of US\$250 per day.

Another woman, office worker Astrid Safiera, began an online seafood business with her husband during the pandemic using Twitter to market their goods and rideservice apps for deliveries. She used creative promotion to initiate the business: She replied to a tweet by former Minister of Maritime Affairs and Fisheries Susi Pudjiastuti (a high-profile social media user) which resulted in 100 'likes' for her tweet.

Meanwhile, in Bekasi on the outskirts of Jakarta, mother Dian Lestari shifted from only supplying red onions into selling cookies during the pandemic. As the Islamic fasting month arrived, she began selling cakes, garlic bread, and dim sum. Promoting her goods through Instagram, existing social contacts, and word-ofmouth, with initial capital of US\$15, within a month her net income from baking surpassed her monthly income as a formal employee. These businesses are acts of resisting and recovering from the impact of COVID-19; and demonstrate creativity and resilience in times of crisis.

\section{Resilience of the informal}

COVID-19 has disproportionately impacted women workers. They are particularly vulnerable because they are overrepresented in sectors hit hardest by the pandemic such as hospitality, education, and care. A recent report by PROSPERA (Australia Indonesia Partnership for Economic Development) indicates that women represent the majority of workers in education (61\%), hospitality (wholesale retail, food, restaurants, accommodation; 59\%), and a majority of women (74\%) in the hospitality sector work under insecure arrangements, ie no formal contracts. It is clear that 
COVID-19 has magnified employment vulnerability for women workers.

Conditions within households are no less dire. In Asia and the Pacific, women spend 4.1 times more time than men in doing unpaid care work. This typically involves tending to other members of the family through cooking, cleaning, and assisting children with school. This situation is not uniquely Indonesian. In the US, Canada, Australia and New Zealand, women are also losing jobs faster than men because of the COVID-19 pandemic, while they are also doing more unpaid work in their households. Women's care burden is exacerbated with/during the school closures, as around 39 percent of Indonesian women who do paid work have at least one primary-school aged child. Such household and care work, while crucial, goes uncompensated and largely unnoticed.

It is also apparent that returning to the pre-crisis situation is not the solution-change is needed. The women in greater Jakarta (and elsewhere) creating, supporting, and digitising informal food networks to suit their food and income requirements provides just one suggestive example. Research that carefully documents how such individuals and their communities respond constructively to crises is necessary. Such studies could provide insights into how households and governments might strengthen food networks by leveraging local food opportunities, short food chains, and digital networks, especially to prepare for future crises.

However, some caution when explicating the creative ways women stay afloat is needed. Such creative solutions, if not unpacked, could lump the destructive impacts of flexibility-which includes precarity, self-exploitation, and structural injustice-and mask it as "resilience". Philanthropist Melinda Gates, for instance, stated that caregiving disruptions during professional online meetings can humanise parents. What she meant by this is that such disruptions push parents to find a new balance between parenting and working by including their children in the digital workspace-albeit by accident. While this may be the case, this statement also disguises the constant competition between unpaid and paid labour usually disadvantaging women, as well as the inequities of race and class. This means that 
care work is even less likely to be recognised for those not participating in such online meetings and/or those not able to work from home), perpetuating the privilege.

It is with this concern that we approach thinking about the creative ways women in greater Jakarta seek to improve household food security and income by means of informal food networks and their digitisation. The salient ability to manage the nutrition in the household and beyond through creative ways amid inevitabilities of crisis must be further researched and mainstreamed into policy. However, this is not sufficient. Fundamental and systemic changes to labour markets and food systems are needed.

Authors: Dr. Inaya Rakhmani, Dr. Ariane Utomo, Dr. Catherine Phillips, Dr. Diahhadi Setyonaluri.

Related webinar: Governance or social resilience: Learning from Southeast Asia's experience with COVID-19.

Image: Food vendors in Jakarta. Credit: zol m/Flickr. 